\title{
Note \\ OCCURRENCE AND BIOLOGICAL ASPECTS OF THE CLITORIA TREE PSYLLID IN BRAZIL
}

\begin{abstract}
Manoel Guedes Corrêa Gondim Junior*; Reginaldo Barros; Fernando Rodrigues da Silva; Geraldo José Nascimento de Vasconcelos

UFRPE - Depto. de Agronomia/Fitossanidade, 52171-900 - Recife, PE - Brasil.

*Corresponding author <mguedes@ufrpe.br>

ABSTRACT: Clitoria fairchildiana (Howard) is a tree largely distributed in Brazil, used for urban arborization. In April 2001, the psyllid Euphalerus clitoriae Burckhardt \& Guajará was reported on this plant in the metropolitan areas of Recife, PE, Brazil. This report records the occurrence of E. clitoriae and studies some of its biological aspects in this area. With this purpose, $C$. fairchildiana leaves were sampled weekly, and $E$. clitoriae nymphs as well as Aprostocetus sp. larvae and nymphs were collected and counted. The E. clitoriae population ranged from 2 to 90 nymphs per leaflet. The Aprostocetus sp. percentage of parasitism ranged from 3 to $24 \%$. The frequency curve for pygidium width ranged from 120 to $140 ; 200$ to $240 ; 300$ to $380 ; 460$ to 580 , and 720 to $820 \mu \mathrm{m}$ for the first, second, third, fourth, and fifth instars, respectively. The incubation period for E. clitoriae eggs lasted 7.6 days. The nymphal stage lasted 5.7; 4.5; 4.8; 5.0, and 6.1 days for the first, second, third, fourth, and fifth instars, respectively. Development time from egg to adult was 33.7 days. Female longevity 8.6 days, with a daily fecundity of 118 eggs. The total viability of the immature stage was $74 \%$, and the sex ratio was 0.5 .

Key words: Euphalerus clitoriae, Psyllidae, biology, biological control, natural enemies
\end{abstract}

\section{OCORRÊNCIA E ASPECTOS BIOLÓGICOS DO PSILÍDEO DO SOMBREIRO NO BRASIL}

\begin{abstract}
RESUMO: O sombreiro Clitoria fairchildiana (Howard) é uma planta amplamente distribuída no Brasil sendo muito utilizada em arborizações. Em abril de 2001 foi constatada a ocorrência do psilídeo Euphalerus clitoriae Burckhardt \& Guajará neste hospedeiro na Região Metropolitana do Recife, PE. Este trabalho teve como objetivo registrar a ocorrência de E. clitoriae e seus inimigos naturais, e estudar alguns aspectos da biologia deste psilídeo. Foram realizadas coletas semanais de folhas de C. fairchildiana visando à contagem de ninfas de E. clitoriae e formas imaturas e adultos dos inimigos naturais. A população de $E$. clitoriae variou de 2 a 90 ninfas por folíolo. A percentagem de parasitismo de Aprostocetus sp. variou de 3 a $24 \%$. A curva de freqüência da largura do pigídio dos insetos observados apresentou variação de 120 a 140; 200 a 240; 300 a 380; 460 a 580 e 720 a $820 \mu \mathrm{m}$ para o primeiro, segundo, terceiro, quarto e quinto ínstares, respectivamente. Os ovos de $E$. clitoriae apresentaram 7,6 dias de incubação. A fase ninfal apresentou 5,7 dias para o primeiro ínstar, 4,5 dias para o segundo ínstar, 4,8 dias para o terceiro ínstar, 5,0 dias para o quarto ínstar e 6,1 dias para o quinto ínstar. O período de ovo-adulto foi 33,7 dias, a longevidade de fêmeas foi 8,6 dias e a fecundidade de 118 ovos/fêmea. A viabilidade total de formas imaturas foi de $74 \%$ e a razão sexual de 0,5 .

Palavras-chave: Euphalerus clitoriae, Psyllidae, biologia, controle biológico, inimigos naturais
\end{abstract}

\section{INTRODUCTION}

The clitoria tree, Clitoria fairchildiana (Howard) (Fabaceae: Papilionoidea) is commonly used as an urban tree in several states in Brazil (Guajará et al., 2003). In the city of Recife-PE, this species is used either for urban arborization of streets, squares, and gardens, or in parking lots as a shade tree. In May 1999, this species was reported as a host for the psyllid Euphalerus clitoriae Burckhardt \& Guajará, in the city of Seropédica-RJ (Burckhardt \& Guajará, 2000).
Psyllids are small, soft-bodied insects, measuring 2 to $5 \mathrm{~mm}$ in length, resembling miniature cicadas. They have three ocelli, with well-developed and usually tensegmented antennae, jumping hind legs in the adult, dimerous tarsal claws, and membranous wings (Borror \& DeLong, 1988).

E. clitoriae preferentially colonizes the abaxial surface of leaflets, laying its egg masses along the veins (Santos et al., 2000a). Upon hatching, the first instar nymphs are mobile and devoid of coating; the production of a whitish waxy mass begins toward the end of the 
first instar, under which the nymphs are protected (Guajará et al., 2002). This insect causes severe damage to the clitoria tree, continuously sucking young branches and leaves, which become yellow and then fall (Docile et al., 2000).

At present, several studies were conducted in order to clarify behavioral and biological aspects of this insect on $C$. fairchildiana in the State of Rio de Janeiro (Docile et al., 2000; Santos et al., 2000a; Guajará et al., 2002; 2003). In April 2001, the occurrence of E. clitoriae was verified in clitoria tree plants from several localities in the cities of Recife, Olinda, Jaboatão dos Guararapes, and Cabo de Santo Agostinho, in the State of Pernambuco. This study was carried out to record the occurrence of $E$. clitoriae and its natural enemies in the city of Recife on C. fairchildiana, and to study some aspects of its biology, such as duration of the immature stages, longevity, fecundity, and total viability.

\section{MATERIAL AND METHODS}

The research was performed in a laboratory under the following conditions: $26 \pm 0.5^{\circ} \mathrm{C}, 65 \pm 10 \%$ R.H., and $12 \mathrm{~h}$ photophase. $C$. fairchildiana leaves were collected between the months of July 2001 and May 2002, in the city of Recife, PE, Brazil $\left(08^{\circ} 01^{\prime} 02^{\prime \prime} \mathrm{S}\right.$ and $\left.34^{\circ} 56^{\prime} 43^{\prime \prime} \mathrm{W}\right)$. To accomplish this, ten trifoliolate leaves from the middle part of the branches of four adult plants were collected weekly. The leaves were taken to the laboratory and the numbers of E. clitoriae nymphs and natural enemies were tallied.

To obtain seedlings, $C$. fairchildiana seeds were planted in $250 \mathrm{~mL}$ capacity plastic cups, using a clay loam soil and earthworm humus at a 4:1 ratio as substrate. The cups were watered daily, and 15 days after planting the seedlings showed only the first pair of leaves; plants at this stage were used to rear E. clitoriae. Adults were collected in the field, brought to the laboratory, and confined for eight hours in cages containing 15-day old plantlets. The cages consisted of plastic tubes $10 \mathrm{~cm}$ in length and four centimeters in diameter. The lid was cut out and drilled in the middle to allow the plantlet stem to be inserted through it. The base of the tube was cut out and a fine screen was glued in place to allow aeration.

Plantlets containing eggs between zero and eight hours of age were observed every 12 hours to determine the incubation period. After hatching and at every ecdysis, 20 nymphs had their pygidia measured with an ocular micrometer attached to a stereoscopic microscope to determine the number of instars. After hatching, the nymphs continued to be observed at 12 hours intervals to determine the duration of each instar. Viability of the development stage was also determined.

After emergence, the adults were sexed in order to determine the sex ratio. Males were confined individu- ally in cages for longevity determination. Females were confined in cages with males obtained in the field, which were replaced in case of death, and were observed daily for fecundity and longevity determination.

\section{RESULTS AND DISCUSSION}

\section{Occurrence of $\boldsymbol{E}$. clitoriae and its natural enemies}

Nymphal ectoparasite, belonging to the family Eulophidae, subfamily Tetrastichinae, and genus Aprostocetus were found in all sampled plants. The hymenopterans that belong to species in this genus frequently parasitize spiders and insects belonging to order Orthoptera, Lepidoptera, Coleoptera, Diptera, Hymenoptera, and Hemiptera (Gaines \& Kok, 1999; Hall et al., 2001; Mirchev et al., 2001). Among hemipterans, the species of this genus parasitize aphids, coccids, pseudococcids, and psyllids (LaSalle, 1993; Ulgenturk, 2001). This Aprostocetus species was found in the Recife metropolitan area, ectoparasitizing third-, fourth-, and fifth-instar $E$. clitoriae nymphs.

Mites of the families Cheyletidae and Stigmaeidae were found in laboratory, under the wax layer secreted by the nymphs. Such places are probably used as shelter by the mites, which probably also feed on sugary secretions (honeydew) produced by the psyllids. However, it was observed in the laboratory that these mites are predators on first-instar E. clitoriae nymphs, which still do not present a waxy scale. Mites of the families Cheyletidae and Stigmaeidae are predators frequently found on plants, feeding mainly on mites and occasionally on other small arthropods (Flechtmann, 1975). Cheletogenes ornatus (Canestrini \& Fanzago) is a natural enemy of citrus scale insects and is an important component in combination with other agents for the biological control of scale insects (Avidov, 1970).

Among the predators that belong to Insecta, two coccinellid species were found preying on nymphs of all instars, as well as one species of Neuroptera. These predators were observed attacking E. clitoriae when the infestation was high, but did not remain on the plants when the population was low. Marques et al. (2002) reported the occurrence of the fungus Cladosporium cladosporioides (Fres.) De Vries on E. clitoriae in the city of Recife, PE. These authors verified that this pathogen infects nymphs, producing a parasitism rate of up to $12.5 \%$.

The E. clitoriae population ranged from approximately 2 to 90 nymphs per leaflet, with an average of 26.6 , between the months of July/01 to May/02. The population peak occurred between the months of December/01 and January/02 (Figure 1). Other authors observed means of 19 and 60 nymphs per leaflet, for the same psyllid on clitoria tree (Docile et al., 2000; Santos et al., 2000b). The parasitism percentage by Aprostocetus sp. 
ranged from 3 to $24 \%$, and the highest parasitism occurred at the beginning of the evaluation, between the months of July and September/01, decreasing to lower values when the highest host population density was verified around the months of December/01 and January/02. As time went by, the E. clitoriae population increased considerably, as well as the population of Aprostocetus sp., despite the fact that the parasitism percentage decreased. This, in addition to the fact that Aprostocetus is not a genus frequently associated with insects in the family Psyllidae, suggests that E. clitoriae probably is not a preferential host for this parasitoid.

The E. clitoriae population increased considerably from August to November 2001, when lower precipitation and relative humidity prevailed, with higher temperatures, and was considerably reduced from March to July, when greater precipitation and relative humidity prevailed, with lower temperatures. Sahu \& Mandal (1999) studied the seasonality of Euphalerus vittatus on Cassia fistula in the western part of Bengala and verified a greater occurrence of the psyllid during the months with milder temperatures and higher relative humidity.

During the period of higher E. clitoriae population density, C. fairchildiana plants presented a large number of yellow leaves and marked leaf shedding. Faeth et al. (1981); Stiling \& Simberloff (1989); and Stromgren \& Lanciani (2001) also verified leaf shedding in plants
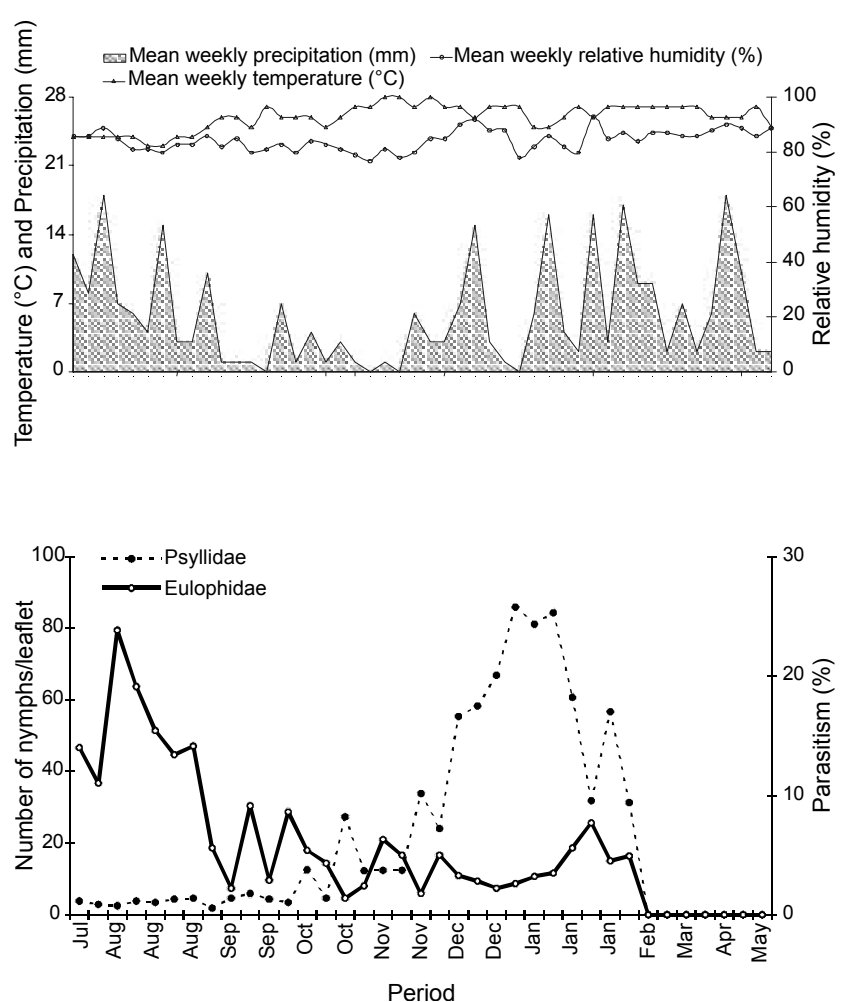

Figure 1 - Population fluctuation of Euphalerus clitoriae and Aprostocetus sp. clitoria tree (Clitoria fairchildiana), between July 2001 and January 2002. infested with psyllids. Although leaf shedding for this species is an intrinsic trait, apparently E. clitoriae has highlighted this fact, since this is a deciduous species; this aspect has been verified by other authors as well, such as Santos et al. (2000a) and Docile et al. (2000).

\section{E. clitoriae Biology}

The psyllid adults oviposited individual eggs or laid them in clusters. The eggs were elongated, stalked, and laid preferentially on younger parts of the plant, such as shoots and young leaves, having a yellowish-green color, becoming black after a period of 24 to 48 hours. Conceição et al. (2000a) also observed the same color changing aspect in E. clitoriae eggs. The first-instar nymphs became fixed near the egg and started feeding on the leaves, secreting a small amount of wax. In the second instar, they started secreting a larger amount of wax, forming a whitish scale that entirely covered the body. This wax layer was observed in subsequent instars. Leaves with high psyllid infestations showed their abaxial surfaces completely covered with a large amount of white waxy material, secreted by the nymphs. These aspects have been reported by Guajará et al. (2002).

The pygidium in E. clitoriae was covered by a chitinous plate, which did not vary in size along each instar. The frequency curve built from the insect pygidium width measurements showed variations from 120 to 140 (first instar), 200 to 240 (second instar), 300 to 380 (third instar), 460 to 580 (fourth instar), and 720 to $820 \mu \mathrm{m}$ (fifth instar) (Figure 2). The growth ratios between instars (Table 1), varied from 1.48 to 1.54 . These values agree with Dyar's rule and can therefore be applied to insects of the family Psyllidae, using the pygidium width as a parameter.

The incubation of E. clitoriae eggs lasted 7.6 days on average; this value was close to that reported by Guajará et al. (2003) for the same host. The nymphal stages had the following durations: 5.7 days for the first instar; 4.5 days for the second instar; 4.8 days for the third instar; 5.0 days for the fourth instar; and 6.1 days for the fifth instar. The egg-adult period lasted 33.7 days, female

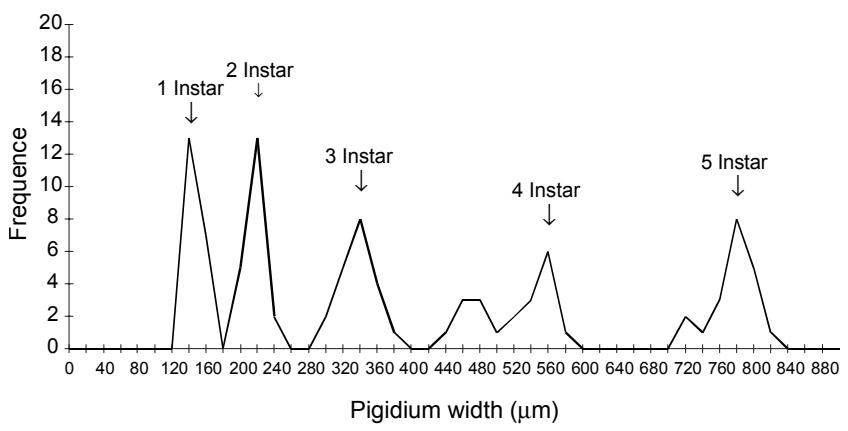

Figure 2 - Euphalerus clitoriae pygidium width frequency curve on clitoria tree (Clitoria fairchildiana), expressed in micrometers. 
Table 1 - Mean pygidium width in Euphalerus clitoriae nymphs, expressed in micrometers, and growth ratio.

\begin{tabular}{lcc}
\hline Instar & Pygidium Width $(\mu \mathrm{m})$ & Growth Ratio \\
\hline & Mean $\pm \mathrm{s}(\mathrm{m})$ & \\
I & $147 \pm 2$ & 1.48 \\
II & $217 \pm 3$ & 1.55 \\
III & $337 \pm 5$ & 1.54 \\
IV & $518 \pm 10$ & 1.50 \\
V & $776 \pm 6$ & --- \\
\hline
\end{tabular}

Table 2 - Euphalerus clitoriae development time and longevity (days), and fecundity (number of eggs per female) on butterfly pea (Clitoria fairchildiana) at $26 \pm 0.5{ }^{\circ} \mathrm{C}, 65 \pm 10 \% \mathrm{RH}$ and $12 \mathrm{~h}$ photophase.

\begin{tabular}{lrrrr}
\hline Stage/Parameter & No. $^{1}$ & Min. $^{2}$ & Max. $^{3}$ & Mean $\pm \mathrm{s}(\mathrm{m})^{4}$ \\
\hline Egg & 97 & 7 & 9 & $7.6 \pm 0.07$ \\
\hline Nymph I & 74 & 4.5 & 7 & $5.7 \pm 0.09$ \\
Nymph II & 52 & 3.5 & 6.5 & $4.5 \pm 0.08$ \\
Nymph III & 50 & 4 & 6 & $4.8 \pm 0.09$ \\
Nymph IV & 37 & 4 & 6.5 & $5.0 \pm 0.12$ \\
Nymph V & 32 & 5 & 7.5 & $6.1 \pm 0.12$ \\
Egg-Adult & 32 & 29 & 39 & $33.7 \pm 0.47$ \\
\hline Longevity & 22 & 5 & 14 & $8.6 \pm 0.60$ \\
\hline Fecundity & 22 & 47 & 268 & $117.6 \pm 4.2$ \\
\hline
\end{tabular}

${ }^{1}$ Number of observations, ${ }^{2}$ Minimum observed value, ${ }^{3}$ Maximum observed value, ${ }^{4}$ Mean and standard deviation.

longevity was 8.6 days, and the females showed a mean fecundity of 118 eggs (Table 2). E. clitoriae has been mentioned by other authors as having an egg-adult period of 34 days, longevity of 9.17 days, and total fecundity of 225.29 eggs per female (Conceição et al., 2000b; Guajará et al., 2003).

Total viability of the immature forms was $74 \%$, with a sex ratio of 0.5 . Similar values were observed by Tsai \& Liu (2000), who studied the biology of Diaphorina citri under similar conditions as those verified here, and observed a total viability ranging from 68.6 to $84.6 \%$.

E. clitoreae is a recent pest in the Recife Metropolitan Area and occurs at high infestations, causing serious damage to clitoria tree plants. This pest is partially controlled by some ectoparasitoid and predator species, and possibly by pathogens as well, and suffers the influence of climatic factors. Apparently, some of these agents are nonspecific; however, with time it is likely that these natural enemies will become adapted; this, in addition to environmental factors, may keep the pest equilibrium level at lower values than at present.

\section{ACKNOWLEDGEMENTS}

To Dr. Ayres de Oliveira Menezes Júnior, from Universidade Estadual de Londrina-PR, for identifying the parasitoid Aprostocetus sp. (Hymenoptera: Eulophidae).

\section{REFERENCES}

AVIDOV, Z. Biology of natural enemies of citrus scale insect and the development of methods for their mass production. Jerusalém: Hebrew University, 1970. 247p.

BORROR, D.J.; DeLONG, D.M. Introdução ao estudo dos insetos. São Paulo: Edgard Blücher, 1988. 653p.

BURCKHARDT, D.; GUAJARÁ, M. Euphalerus clitoriae sp. n., a new psyllid species from Clitoriae fairchildiana (Fabaceae: Papilionoideae), and notes on other Euphalerus spp. (Hemiptera, Psylloidea). Revue Suisse de Zoologie, v.107, p.325-334, 2000.

CONCEIÇÃO, J.C.; CERQUEIRA, B.; GUAJARÁ, M.; CARVALHO, A.G. Aspectos da oviposição em Euphalerus clitoriae (Hemiptera: Psyllidae). In: CONGRESSO E EXPOSIÇÃO SOBRE FLORESTAS, 6., Porto Seguro, 2000. Resumos técnicos. Porto Seguro: Instituto Ambiental Biosfera, 2000a. p.450.

CONCEIÇÃO, J.C.; CERQUEIRA, B.; SANTOS, W.; GUAJARÁ, M.; CARVALHO, A.G. Longevidade do adulto de Euphalerus clitoriae sp.n. (Hemiptera: Psyllidae). In: CONGRESSO E EXPOSIÇÃO SOBRE FLORESTAS, 6., Porto Seguro, 2000. Resumos técnicos. Porto Seguro: Instituto Ambiental Biosfera, 2000b. p.531.

DOCILE, A.F.M.; GUAJARÁ, M.; MAURÍCIO, E.G.; FERRAZ, F.C.; CARVALHO, A.G. Ocorrência de Euphalerus clitoriae sp. n. (Hemiptera, Psylloidea) em Clitoria fairchildiana, Maricá, RJ. Floresta, v.30, p.190, 2000.

FAETH, S.H.; CONNER, E.F.; SIMBERLOFF, D. Early leaf abscission: a neglected source of mortality of folivores. American Naturalist, v.117, p.409-415, 1981

FLECHTMANN, C.H.W. Elementos de acarologia. São Paulo: Nobel, 1975. 344p.

GAINES, D.N.; KOK, L.T. Impact of hyperparasitoids on Cotesia glomerata in southwestern Virginia. Biological Control, v.14, p.19-28, 1999.

GUAJARÁ, M.; CARVALHO, A.G.; GONÇALVES, K.; NASCIMENTO, S.; SILVA, J.W.P. Descrição dos ínstares ninfais de Euphalerus clitoriae Burckhardt \& Guajará (Hemiptera: Psyllidae). Revista Universidade Rural Série Ciências da Vida, v.22, p.211-215, 2002.

GUAJARÁ, M.; CARVALHO, A.G.; SANTOS, W.; GONÇALVES, K. Aspectos da Biologia de Euphalerus clitoriae Burckhardt \& Guajará, 2000 (Hemiptera: Psyllidae) sob Condições de Campo. Floresta e Ambiente, v.10, p.69-75, 2003.

HALL, D.G.; PENA, J.; FRANQUI, R.; NGUYEN, R.; STANSLY, P.; McCOY, C.; LAPOINTE, S.L.; ADAIR, R.C.; BULLOCK, B. Status of biological control by egg parasitoids of Diaprepes abbreviatus (Coleoptera: Curculionidae) in Citrus in Florida and Puerto Rico. BioControl, v.46, p.61-70, 2001.

LaSALLE, J. North American genera of Tetrastichinae (Hymenoptera: Eulophidae). Journal of Natural History, v.28, p.109-236, 1993.

MARQUES, E.J.; FRANÇA, I.W.B.; MENEZES, M. Ocorrência de Cladosporium cladosporioides (Fres.) De Vries em Euphalerus clitoriae Burckhardt \& Guajará, 2000 (Hemiptera: Psyllidae) em Clitoria fairchildiana no Estado de Pernambuco. In: CONGRESSO BRASILEIRO DE ENTOMOLOGIA, 19., Manaus, 2002. Resumos. Manaus: INPA, 2002. p.78.

MIRCHEV. P.; GEORGIEV, G.T.; TSANKOV, G. Studies on the parasitoids of Gelechia senticetella (Stgr.) (Lepidoptera: Gelechiidae) in Bulgaria. Anzeiger fuer Schaedlingskunde, v.74, p.94-96, 2001.

SANTOS, W.; GONÇALVES, K.; GUAJARÁ, M.; CARVALHO, A.G. Teste de Preferência de Cor por Euphalerus clitoriae (Hemiptera: Psyllidae) In: CONGRESSO E EXPOSIÇÃO INTERNACIONAL SOBRE FLORESTAS, 6., Porto Seguro, 2000. Resumos técnicos. Porto Seguro: Instituto Ambiental Biosfera, 2000a. p.592-593. 
SANTOS, W.; GUAJARÁ, M.; CONCEIÇÃO, J.C.; GONÇALVES, K. Relação entre intensidade populacional de Euphalerus sp e severidade de ataque em Clitoria fairchildiana. In: CONGRESSO BRASILEIRO DE ZOOLOGIA, 23., Cuiabá, 2000. Programas e resumos. Cuiabá: SBZ, 2000b. p.217.

SAHU, S.R.; MANDAL, S.K. Seasonal activity of amaltas psyllid Euphalerus vittatus Crawford (Psyllidae: Hemiptera). Environmental and Ecology, v.17, p.509-510, 1999.

STILING, P.; SIMBERLOFF, D. Leaf abscission: induced defense against pest or response to damage. Oikos, v.55, p.43-49, 1989.

STROMGREN, E.S.; LANCIANI, C.A. Early abscission in hackberry leaves bearing Pachypsylla galls (Homoptera: Psyllidae). Florida Entomologist, v.84, p.727-728, 2001.
TSAI, J.H.; LIU, Y.H. Biology of Diaphorina citri (Homoptera: Psyllidae) on four host plants. Journal of Economic Entomology, v.93, p.1721$1725,2000$.

ULGENTURK, S. Parasitoids and predators of Coccidae (Homoptera: Coccoidea) species on ornamental plants in Ankara, Turkey. Acta Phytopathologica et Entomológica Hungarica, v.26, p.369-375, 2001.

Received December 12, 2003

Accepted April 14, 2005 